\title{
HERITAGE PRESERVATION AS A PUBLIC DUTY: THE ABBÉ GRÉGOIRE AND THE ORIGINS OF AN IDEA $\dagger$
}

\author{
Joseph L. Sax*
}

Public responsibility for the conservation of artifacts of historic or aesthetic value is now acknowledged everywhere. One way or another the state will ensure preservation of a Stonehenge or a Grand Canyon as well as a great many lesser cultural icons. We have names for such things - "heritage" and "cultural property" are two of them; "patrimony" is a European counterpart - but these words have no very specific meaning. Many, but by no means all, of the objects we feel constrained to protect are old. They include human artifacts as well as natural objects or places. Though it is customary to say that no one has a right to destroy those things comprising our heritage, many such items, especially works of art, are held and enjoyed as ordinary private goods without public access or regulation of any kind.

This inconsistency illustrates the paradox of historical preservation. As uncontroversial as heritage preservation may appear when one thinks of historic monuments and artistic masterworks, the idea of an officially designated culture seems greatly at odds with modern sensibilities. The very idea of government involving itself in cultural life raises the unwelcome specter of censorship on one side and official propaganda on the other. In addition, there is the more general question of cultural policy as a tool of a paternalistic state that aspires to make its citizens good, a notion that has lost all cachet in our time. In short, state cultural policies appear to be out of harmony with modern ideas about the role of government. Nonetheless they flourish. Obviously there is some very strong attraction to the idea of a common heritage: a people and a community bound together in some shared enterprise with shared values.

How did protection of cultural values come to be viewed as a proper public concern in a modern world centered on the liberty and autonomy of the individual? The pages that follow trace out one historical strand of the story in the hope of casting some light into this

† (C) 1990 by Joseph L. Sax.

* James H. House and Hiram H. Hurd Professor of Law, University of California, Berkeley. A.B. 1957, Harvard; J.D. 1959, University of Chicago. - Ed. 
rather obscure corner of public policy. ${ }^{1}$

As we shall see, there is no deep-rooted theory or philosophy of preservation. The idea that there is some collective obligation to identify and protect cultural artifacts is quite modern. ${ }^{2}$ Only a century ago, the private owner of Stonehenge threatened to sell it. And as recently as 1910, when a syndicate of speculators threatened to pull down the unique fifteenth-century Tattershall Castle, no law in England permitted the government to intervene through its power of eminent domain. ${ }^{3}$

Periodically, a monarch would show sensitivity to preservation for historic or aesthetic reasons, ${ }^{4}$ and society has always identified some things as beautiful or memorable. Such things were saved and passed along through generations. Other things, such as religious relics, were treated as special forms of property deserving veneration. ${ }^{5}$ But for most things, and for most of history, neglect or iconoclasm were far more common than protection. ${ }^{6}$ It took a long time for the idea of heritage to be formulated as a public concern and to become the subject of public discourse. And when it happened, it did so in the most unlikely setting.

The place was revolutionary France and the year 1794. Out of a reign of destruction came a plea, a theory, and a plan for protection of cultural artifacts, the genesis of modern preservationist thought. The worst excesses of the Terror had not yet subsided when the revolutionary government asked one of its members, Henri Grégoire, to suggest a response to a proposal to destroy, as unrevolutionary, all Latin inscriptions on monuments. Preparation of the report, dated January 8, 1794 , induced Grégoire to reflect on the reasons counseling public pro-

1. There is some literature on the subject. See especially Merryman, The Public Interest in Cultural Property, 77 CALIF. L. REV. 339 (1989), which cites many relevant sources. For a highly individual effort to probe the meaning of preservation, see M. GUILLAUME, LA POLITIQUE DU PATRIMOINE (1980). A. RIEGL, LE CULTE MODERNE DES MONUMENTS: SON ESSENCE ET SA GENESE (D. Wieczorek trans. 1984) comes the closest to a theoretical study of the area. The best book in English on historic preservation with a comprehensive bibliography is $D$. Lowenthal, The Past Is a Foreign Country (1985).

2. G. Baldwin Brown sets out the early history of historic preservation legislation in his fine book G.B. Brown; The Care of ANCIENT Monuments (1905).

3. Both examples are given in W. KenNet, Preservation 32-33, 37 (1972).

4. G.B. BrowN, supra note 2, at 13, mentions Hadrian; Cassiodorus, who served Theodoric of Rome and Ravenna; and Eginhard, who served Charles the Great.

5. See Babelon \& Chastel, La notion de patrimoine, 49 REVUE DE L'ART 5, 6 (1980).

6. There has been extensive chronicling of historic destruction. Among the more interesting studies are P. Burke, The Renaissance Sense of the Past (1969); C. Dellheim, The Face of the Past: The Preservation of the Medieval INHeritance in Victorian ENGland (1982); J. Grant, A Pillage of ART (1966); and R. LANCiani, The Destruction OF ANCIENT ROME (1899). 
tection of antiquities. This report was the first in a series of wideranging discourses on cultural policy made by this remarkable man.

Beginning in August of 1794, Grégoire produced the three reports to the National Convention for which he is best known. The first is entitled Report on the Destruction Brought About by Vandalism, and on the Means to Quell It. Each report was originally requested only as an account of the losses the nation was sustaining. ${ }^{7}$ But Grégoire used the opportunity to consider a question that had never before been the subject of legislative attention: Why should caring for paintings, books, and buildings be a concern of the nation? Why, especially in a republic that was beginning radically anew, should monuments ${ }^{8}$ redolent of the values of the old regime be respected? Grégoire's reports, which have never been translated into English, ${ }^{9}$ stand as the first expression of what has become a modern public policy on cultural property. ${ }^{10}$ These reports, and their background, are the subject of this article.

What has this remote series of events, with destructive mob vio-

7. Grégoire's writings are not easily accessible. There is a quite unsatisfactory, unedited, and incomplete multi-volume edition of his works, published by Kraus-Thomson of Liechtenstein, which simply reprints copies of eighteenth-century editions, and which carries the name of no editor. 1-14 H. GrÉgoIRe, OEuVRes DE L'ABbE GrÉgoIre (Kraus-Thompson Organization, Ltd., 1977) [hereinafter OeUVREs]. A more recent book provides the text of 10 of Grégoire's most important discourses, but it does not include those on revolutionary vandalism. It also contains a brief but useful introduction. L'ABBE GREGOIRE, EVEQUE DES LUMIÈrES (F. Bowman ed. 1988) [hereinafter L'ABBE GREGOIRE]. All three of Grégoire's reports on vandalism, and several other writings in addition, are reprinted (in French) at the end of W. AsHBouRNE, GREgoIRE AND THE FRENCH REvolution (n.d.). The three reports on vandalism are also found in 2 OEUVRES, supra, at 257, 321, and 335. They are entitled: (1) Rapport sur les destructions opérées par le vandalisme, et sur les moyens de le réprimer, séance du 14 Fructidor, l'an II; (2) Second rapport sur le vandalisme, séance du 3 Brumaire, l'an III; (3) Troisième rapport sur le vandalisme, séance du 24 Frimaire, l'an III.

8. "Monument" is the technical term generally used in Europe for those things, usually of historical interest, that are officially preserved. It need not be a building or structure, as we usually think of a monument in this country, but may also denote moveable items that are found in museums. The term "monument historique" was first used in France in 1790. F. RÜcKER, LES ORIGINES DE LA CONSERVATION DES MONUMENTS HISTORIQUES EN FRANCE (1790-1830), at $180 \mathrm{n.1}$ (1913). Rücker's work, a doctoral thesis at the University of Paris, is the source of much of the information we have about preservation policy during the revolutionary period. All subsequent writers are greatly in his debt. But see Babelon \& Chastel, supra note 5 , at 8 (attributing the first use of the term "monument" to describe heritage property to the scholar-priest Bernard de Montfaucon (1655-1741)).

9. I have been able to find only two of Grégoire's works translated into English: Grégoire, Motion on Behalf of the Jews, and Grégoire, $A$ Report on Behalf of the Colored People of St. Domingue and Other French Islands in America, Addressed to the National Assembly. Both are found in Two Rebel. Priests of the French Revolution (R. Carol ed. 1975).

10. Even before Grégoire's report, another member of the revolutionary government, Joseph Lakanal, had posed before the 1792 Constitutional Convention the problem of the destruction of cultural artifacts. However, Lakanal's "intervention came to naught - perhaps because of the presence of Robespierre, whose disdain for material things was well known." Psichari, Grégoire, Père des lettres, des sciences et des arts, 34 EuRope, Aug.-Sept. 1956, at 115, 118. All three of Grégoire's reports on vandalism followed Robespierre's execution in July 1794, although Gré- 
lence arising out of the white heat of revolutionary turmoil, to do with us, and with our quiet present-day disputes over the fate of an urban landmark or an indigenous burial ground? Grégoire saw himself engaged in combat with what he called the axioms of ignorance. ${ }^{11}$ His adversaries, he said, were those who, after having heard the reading of a fine tragedy, said: "What does that prove?"12 Grégoire's views were based in ideas about the promise of freedom and how it could be kept. Perhaps he has something to say to our time and our circumstances.

\section{INTRODUCING THE ABBE GREGoIRE}

Henri Grégoire, ${ }^{13}$ who is always called the Abbé Grégoire, ${ }^{14}$ is well known in France, though he is probably little read even in his own country. Grégoire was a man of many parts. He is remembered primarily for his campaigns to abolish the slave trade in the French colonies $^{15}$ and for obtaining equality and full rights of citizenship for the

goire anticipated much of their content in his report on inscriptions in January 1794, six months before Robespierre went to the guillotine.

Other members of the government worked to save monuments. For example, on November 30, 1792, Jean-Marie Roland de la Platière, the Minister of the Interior,

sent instructions that anything whose artistic value was greater than its metallic value, any monument originating before 1300 and anything that shed light on the history of art or moeurs [manners] should be saved .... . When [Joseph] Garat took office in early 1793 he saw the problem as one of speeding up the organization of existing collections so that they could be opened to the public.

Kennedy, Remarks on Stanley Mellon's Alexandre Lenoir: The Museum Versus The Revolution, in The CONSORTIUM ON RevolutionaRy EurOPE 1750-1850, at 89-90 (1979) [hereinafter The Consortium].

11. H. GrÉgolRe, Nouveaux développemens sur l'amélioration de l'agriculture, par l'établissement de maisons d'économie rurale, in 2 OEUVRES, supra note 7, at 132.

12. H. GREGoIRE, Rapport sur les encouragemens, récompenses et pensions à accorder aux savans, aux gens de lettres et aux artistes, in 2 OEUVRES, supra note 7, at 305-06.

13. Surprisingly, there is no modern or full-scale biography of Grégoire, even in French. The most recent works are B. Plongeron, L'ABBE GREGOIRE: OU L'ARCHE DE LA FRATERNItE (1989), and P. FAUChON, L'ABBE GREgoIRE: LE PRETRE-CITOYEN (1989). There are two rather limited biographical works on Grégoire in English. R. NEChELES, THE ABBE GrÉgoIRE, 1787-1831: THE ODYSSEY OF AN EGALITARIAN (1971) is a study of Grégoire's work toward the emancipation of slaves, and for equal treatment of the Jews. See also W. AsHBourne, supra note 7. The original source of most information on Grégoire is the lengthy introduction to his memoirs by Hyppolyte Carnot, published in 1840 . The Carnot work was separately published as a book. H. CARNOT, HENRI GREGOIRE, EVEQUE REPUBLICAIN (1882); see also L. MAGGIOLO, LA VIE ET LES cEUVRES DE L'ABbE GREGOIRE DE 1750 A 1789 (1873); P. GRUNEBAUM-BaLLIN, L'ABBE GREGOIRE (1936). Grégoire's memoirs and a revised version of Carnot's introduction were published together in 1989. MÉmOIRES DE GREGOIRE, ANCIEN ÉVEQUE DE BLOIS (J.-M. Leniaud ed. 1989) [hereinafter MEMOIREs]. Emmet Kennedy's recent book, E. KENNEDY, A CULTURAL HISTORY OF THE FRENCH REvolution (1989), is unusual in giving Grégoire more than passing reference.

14. Abbé is the French word for abbot. But it would seem as odd calling him Abbot Grégoire as it would speaking of Brother Angelico rather than Fra Angelico.

15. Having achieved the liberation of blacks in the French colonies in 1794, the victory was reversed by Napoleon, and then had to await the revolution of 1848. Abraham, Esclavage, servage, servitude, 34 EuROPE, Aug.-Sept. 1956, at 3-4. 
Jews in France. ${ }^{16}$ He was, above all, an apostle of tolerance and an enemy of both ignorance and the narrow prejudices he believed ignorance fostered.

Grégoire was born to a modest family in 1750 , in the village of Veho in Lorraine. He studied with the Jesuits and became a parish priest in the parish of Ebermesnil, not far from his birthplace. Grégoire was no ordinary rural cleric. He wrote an award-winning study of poetry and garnered honors for his 1788 essay, On the Physical, Moral and Political Regeneration of the Jews. ${ }^{17} \mathrm{He}$ knew seven or eight foreign languages, ${ }^{18}$ studied philosophy, ${ }^{19}$ and traveled to England and extensively in continental Europe, ${ }^{20}$ where he met intellectuals and writers with whom he subsequently carried on an extensive correspondence.

The breadth of Grégoire's interests was extraordinary. He had a deep interest in the French language, in education, in antiquities, agriculture, religious history, artisanal traditions, and - as we shall see presently - in all the artifacts of cultural life. He was concerned with international relations and drafted a remarkable declaration of principles of international law, ${ }^{21}$ as well as a proposal for arbitration of international differences. ${ }^{22}$ There is hardly a subject of modern social

16. Grégoire, Motion en faveur des Juifs, in L'ABBE GrEgoIRE, supra note 7, at 21. An English translation is found in Two REBEL PRIESTS of THE FRENCH REvolution, supra note 9 , at 18. There were a few others, at about the same time, who also took up the cause of the oppressed Jews, among them Pierre-Louis Lacretelle and the Count de Mirabeau. Spire, Autour d'un autographe de l'Abbé Grégoire, 34 Europe, Aug.-Sept. 1956, at 78, 81 nn.1-2.

17. H. GrEgolre, Essai sur la régénération physique, morale et politique des Juifs, in 9 OEUVRES, supra note 7, at 1 .

18. IfETTREs à GrEgoire sur les PATOIS de France, 1790-1794, at 6 (A. Gazier ed. 1969) (reimpression of Paris edition of 1880). But see Grunebaum-Ballin, Panégyrique de Grégoire, 34 EuROPE, Aug.-Sept. 1956, at 8, 15 (suggesting Grégoire knew Latin well and had some knowledge of English, Italian, Spanish, and to some extent German, which was exceptional at that time).

19. He disapproved of Voltaire, but admired Pascal, Arnauld, and Bossuet. Marot, L'Abbé Grégoire et le vandalisme révolutionnaire, 49 REVUE DE L'ART 36, 37 (1980).

20. H. CARnot, supra note 13 , at 106.

21. In 1792, while France was at war with the European powers, Grégoire proposed (unsuccessfully) the adoption of an international Declaration of the Rights of Peoples, of which Article 10 provided: "Each people is the master of its own territory." The full text of the proposed Declaration is set forth in MEMOIRES, supra note 13, at 98-99. After France was victorious he renewed his proposal, pronouncing before the Convention a long discourse in favor of international law, but again his proposal was rejected. Otherwise forgotten, the proposed Declaration was cited by Ho-Chi-Minh in a letter dated July 6,1946. Lyon-Caen, Grégoire et les droits des peuples, 34 Europe, Aug.-Sept. 1956, at 84, 84-85. Professor Lyon-Caen's article also refers to a doctoral thesis by Madame $L$. Chevalley, which provides a more extensive study of the Declaration. See L. Chevalley, La declaration du DRoit des gens de l'AbBE Grégoire (1930). According to L'ABBE GREGOIRE, supra note 7, at 10, Grégoire's proposal echoed the dreams of an international organization of the Abbé Charles-Irenée de Saint-Pierre, who was born some 100 years earlier and was the author of a tract entitled Project of Perpetual Peace.

22. H. CARNOT, supra note 13 , at 55 . 
importance on which he did not have views far in advance of his time. In 1824, when he was seventy-four years old, he published a plan to provide asylum to intellectuals of all countries who were the victims of persecution. ${ }^{23} \mathrm{He}$ even seems to have envisioned a sort of French fortune cookie: he wanted to put sage maxims on children's bonbons. ${ }^{24}$

One writer said of Grégoire that he was perhaps the most original of all the members of the revolutionary Convention, a body in which "singularity was not at all missing." 25 He fit no preconceived categories. For example, many priests, including the Bishop of Paris, abjured their religious status during the Revolution. Though this was a popular way to show one's revolutionary character, Grégoire refused, asserting in a memorable oration that he was "Catholic by conviction and sentiment, a priest by choice .... I invoke the freedom of religion."26 As the editor of the Abbé's memoirs noted, "the royalists detested him as a revolutionary and as being impious, and the philosophers mocked him for his orthodox christianity." 27

Grégoire's political life was long and active. He was named as a representative of the clergy to the original Estates General that met in Versailles in May of 1789, marking the beginning of the Revolution. He remained a prominent participant in the succeeding revolutionary legislatures, and was the president of the National Assembly in 1791. He was among the first to take the oath of the Civil Constitution of the Clergy $^{28}$ and was named constitutional bishop of Blois in the same year.

He continued to be controversial even into old age. He had a sharp tongue and did not hesitate to use it. In response to a speaker who asked in 1814 how the Senate could exist without a head, Grégoire responded with typical directness: "It has gotten on fourteen years now without a heart." 29 As an unrepentant Republican, Grégoire opposed the establishment of the Empire, and was very disap-

23. Id. at 118 .

24. Id. at 62; J. TILD, L'ABBE GREGoIrE 49 (1946).

25. E. DESPOIS, LE VANDALISME REVOLUTIONNAIRE 194 (1885).

26. MEMolres, supra note 13, at 127; Carnot, Notice historique sur Grégoire, in MÉmoIRES, supra note 13, at 234.

27. Carnot, Notice historique sur Grégoire, in MEMOIREs, supra note 13, at 239.

28. The document provided that henceforth bishops would be elected by the electors who nominated the deputies, the judges in the trial courts, and the departmental administrators. Prior to 1790 , bishops had been nominated by the king. With some reservations, Grégoire was able to accept this change, though he was responsible for an amendment to Article 4 providing that it was "without prejudice to the authority and the community of the Supreme Pontiff." J. TILD, supra note 24, at 26-27 (asserting that Grégoire, though critical of the document, adhered to it as a patriotic duty).

29. Carnot, Notice historique sur Grégoire, in MÉmoIREs, supra note 13, at 273. 
proving of Bonaparte, whom he greatly angered by his outspoken criticism, including his refusal to recognize Napoleon's divorce from Josephine. Perhaps it was Grégoire's unbending principle that saved him. After writing Napoleon a rather sharp letter challenging the legitimacy of his crown, Grégoire ended by saying, " $[\mathrm{I}$ am $]$ inaccessible to fear and to ambition .... I shall have lived without cowardice and I want to die without remorse." Furious but obviously admiring of Grégoire's intrepidity, Napoleon said, "he is truly incorrigible." 30 The Abbé's memoirs provide what would have been an apt inscription for his tombstone: "I am like granite. I can be broken, but I cannot be bent." 31

\section{The Setting: The Heritage Tradition as of 1789}

What was the status of public policy as to cultural artifacts prior to the 1790s when Grégoire began developing his views? The simple answer is that there were no policies in the modern sense, and that protective decrees issued by the revolutionary government marked a notable beginning for preservation as a responsibility of the state. Of course, in policy matters, there are no indisputable points of beginning. A concern with the past had been growing for several centuries prior to the French Revolution, and one might point to both earlier and later developments as the crucial events. England was well ahead of France in attending to its own archeology, and Italy was certainly the leader in taking the historical view of civilization. ${ }^{32}$ In France itself, some authorities date the beginnings of modern policy to the French Monument Act of 1887, or to the year 1830, when the post of Inspector of Historical Monuments was first proposed and a budget for the protection of monuments was first appropriated. ${ }^{33}$ Alternatively, one might look back to the sixteenth century, when France instituted a royal depositary of every published book, an act that has been described as the "first example of a conscious cultural policy." 34

It is customary to attribute the beginnings of preservation consciousness to the Italian Renaissance, and most particularly to a famous letter Raphael wrote to Pope Leo X around 1519, lamenting the loss of precious antiquities to the Roman building boom of the fifteenth century. ${ }^{35}$ Papal decrees were issued frequently over the next

30. J. TILD, supra note 24 , at 80 .

31. H. CARNot, supra note 13 , at 116.

32. See Babelon \& Chastel, supra note 5 , at 21.

33. G.B. Brown, supra note 2, at 74, 76.

34. Babelon \& Chastel, supra note 5, at 10.

35. An English translation of the letter appears in 1 A DOCUMENTARY HistoRY OF ART 
several centuries (often with little effect) to prohibit or limit the use of materials from classical structures. Certainly, Renaissance appreciation of antiquity set the stage for the later sense of indebtedness to history that was not felt during the Middle Ages nor during antiquity. ${ }^{36}$ Grégoire himself greatly admired the classical world, and although there is no known evidence that he actually read Raphael's letter, which was published in $1733,{ }^{37}$ his reports echo the sentiments of that document in a quite striking way.

Grégoire is best remembered for his attack on the revolutionary iconoclasts as barbarians whose destruction of France's material heritage was an attack on the nation, and whose acts he characterized by coining the word "vandalism." If he did know of the letter, Grégoire could hardly have forgotten the passage in which Raphael wrote:

[W]hy should we bewail the Goths, the Vandals, and other perfidious enemies of the Latin name, when those who above all others should be fathers and guardians in the defense of the poor relics of Rome, have even given themselves over to the study — long study — of how these might be destroyed and disappear. ${ }^{38}$

In one respect at least, there is no doubt of the influence of Raphael and his Renaissance contemporaries. By the time of the Revolution there was in France, as there was elsewhere in Europe, a passionate admiration for antiquity. A history of the city of Nimes describes the arrival of the French king François $I$ in the sixteenth century:

One saw him, down on one knee cleaning with his handkerchief the dust which covered the letters of the Roman inscriptions, in order to uncover them and read them more easily. Full of admiration for all these grand and ancient marvels of art, he appeared indignant of the little care that was being taken to conserve them and he showed publicly the displeasure he felt at this negligence. ${ }^{39}$

Perhaps because of that visit, the antiquities of Nimes were made the subject of a remarkable ordinance in 1548:

[W]e have seen in passing by [Nimes] fine and grand antique edifices from which connoisseurs take pleasure and benefit from the art and architecture, which is an ornament of the Languedoc and a pride of the

289-96 (E. Holt ed. 1957). Holt attributes the letter to a collaboration between Raphael and Baldassare Castiglione. Id. at 289. For a dating of the letter, see Castagnoli, Raphael and Ancient Rome, in The CoMPlete WORK OF RAPHAEL 569, 582 n.16 (1969).

36. Renaissance thinkers, however, were interested in antiquity as the model of perfection, rather than in the past in general or in achievements of talent at other times and places. $P$. LEON, LA VIE DES MONUMENTS FRANÇAIS: DESTRUCTION, RESTAURATION 16 (1951).

37. Castagnoli, supra note 35 , at 582 n.16.

38. 1 A DOCUMENTARY History OF ART, supra note 35, at 291.

39. 4 L. MÉNART, HistoIre DE LA VILLE DE NIMEs 127 (1753), quoted in Babelon \& Chastel, supra note 5 , at 11 . 
kingdom .... [W]e order ... all the possessors of these antique structures not to demolish them nor permit any new building that could cover or hide them ... unless previously you go there with the king's men of the city, in order to make a visitation . . . .40

The views expressed in this ordinance were a rarity, however. ${ }^{41}$ The prevailing view was that artifacts and especially structures were just ordinary property that existed at the will of their owners.

Pre-Revolution behavior toward cultural properties is almost unimaginable by modern standards. For example, the crown jewels of France, while they were a "material embodiment of the permanence of the monarchy, ... . were no less a reserve of metal and precious stones susceptible to be pawned, pulled apart, sold or melted." 42 Chambord, a royal château in the Loire Valley that is greatly admired today in its restored condition, was thought too expensive to maintain in the seventeenth century, was allowed to deteriorate, and was then put up for sale. 43 Two other châteaux, "Blois and Amboise, after their revival during the wars of religion, were little by little neglected during the seventeenth century. For lack of care they became decrepit. No one rose up in indignation over it."44 François I, who had knelt reverently before the antiquities of Nimes, sold off as lots a number of royal domains in Paris when he was short of cash, in direct contravention of the testament of his predecessor, Charles V.45

Similarly, the remains of old churches would unceremoniously be torn down to make way for new ones, and statues and columns were for centuries routinely recycled as building materials. ${ }^{46}$ Medieval buildings, far from being venerated, were seen as examples of barbarous taste. ${ }^{47}$ Ironically, in light of the destructive frenzy that was to come, some important medieval structures were lost in the pre-Revolutionary decade because the church hierarchy itself wanted to detach people from an excessively materialistic conception of religion. Like

40. Babelon \& Chastel, supra note 5 , at 12 .

41. The originators of the views such ordinances expressed were themselves rarities, as well. Roger de Gaignières was a collector of manuscripts and engravings who travelled all over France. Noting the pitiable state of historic structures, he wrote a remarkably prescient memoir in 1703 recommending that the government issue "a decree of the Council which will prohibit the demolition of monuments unless there is express permission given by those who may be concerned and who will commit a person to go in the provinces and make drawings with the formalities deemed necessary in execution . . . E." Erlande-Brandenbourg, Une initiative mal récompensée, Roger de Gaignières (1642-1715), 49 REVUE DE L'ART 33 (1980).

42. Babelon \& Chastel, supra note 5 , at 9-10.

43. F. RüCKER, supra note 8 , at 200.

44. Babelon \& Chastel, supra note 5, at 12.

45. Id.

46. R. Lanciani, The Destruction of ANCIEnt Rome 28 (1899).

47. J. AIsop, The RARE ART TRadition 11 (1982); E. Despois, supra note 25, at ch. XI. 
the religious iconoclasts in Puritan England a century earlier, ${ }^{48}$ the Church thought it could generate a truer faith by minimizing the importance of physical artifacts. ${ }^{49}$ As for indigenous antiquities, the traditional view was only mildly self-parodied by an Englishman who some years later asked, '[W]hat [is] a 'national monument' anyway? [Are] the 'absurd relics' of our 'barbarian predecessors' who 'found time hanging heavily on their hands and set about piling up great barrows and rings of stones' really to be preserved, and that at the cost of infringement of property rights?"'50

This was the setting and situation of patrimonial property at the time of the Revolution. One could find examples of almost any behavior. Art was appreciated and antiquity admired, yet simultaneously great treasures were sold, neglected, or forgotten and left to the elements. It is fair to say that there was nothing worthy of the name of a theory or a practice of cultural policy.

When the Revolution got underway, it presented a situation without precedent. The expropriation of feudal and ecclesiastical goods, which occurred as an act of revolutionary politics, created a vast store of treasures that formally became collective property..$^{51}$ The seizures made the intervention of the new government in cultural matters inevitable. It was out of those events that a new sort of thinking began. "All these precious objects," the Committee on Public Instruction wrote, "that have been kept away from the people and shown to them only to astonish them, all these riches now belong to the people."52 Directions issued to the local administrators of these properties noted, "You are only the stewards of an estate for which the 'great family" can call you to account." 53 It was this conception of a national heritage that Grégoire later elaborated and developed in his reports.

The change that began with the Revolution was a recasting of a wide range of artistic, scientific, and historical artifacts as secular icons with both instrumental and symbolic content for the new republican nation. As we shall see, Grégoire coined and applied a whole vocabu-

48. See generally J. Philitips, The Reformation of Images: Destruction of ART IN ENGLAND, 1535-1660, at 183-200 (1973).

49. Babelon \& Chastel, supra note 5 , at 8 .

50. W. KENNET, supra note 3, at 25 (quoting Lord Francis Hervey, a lawyer). Serious archeology did not get underway until the mid-nineteenth century. See G. DANIEL, A HuNDRED AND Fifty Years of ARChaEology 10 (2d ed. 1975); J. WorsaAe, The Primeieval ANTIQUiTIES OF DENMARK (1849).

51. F. RÜCKER, supra note 8 , at $19,41-42$.

52. P. LEON, supra note 36, at 63 (citing the Temporary Commission of Arts' instructions on how to conserve and prepare an inventory of objects important for art, science, and education, adopted by the National Convention's Committee on Public Instruction).

53. Id. 
lary of invective in order to characterize destruction as desecration. To recharacterize cultural artifacts in this way was not only to imbue them with a new value, but to create new claims upon them. They became public objects, not only in the ordinary sense of public ownership, but in endowing the public with a portentous stake in their fate.

\section{The Revolutionary Government's Cultural Policy}

The reports of the Abbé Grégoire followed nearly five years of confusion over the fate of artistic, historical, and literary properties. Originally the plan was to sell everything for the benefit of the treasury, but the committee charged with the sale, sensitive to the extraordinary nature of the treasures that had fallen into its hands, proposed the formation of a commission to care for the masterpieces of art, science, and literature in its possession.

In 1790, the Constituent Assembly created a Monuments Commission consisting of distinguished members of various royal academies. The Commission was mandated to collect in warehouses those works of art considered worthy of preservation by the state and to prepare an inventory of the collection. ${ }^{54}$ Despite the turmoil of the times, and though its work was soon to be cut short as destructive forces took charge of events, the Monuments Commission saved some important art and set a precedent of state responsibility for the conservation and provision of cultural properties as heritage goods. ${ }^{55}$ The Commission's work was among the pioneering efforts that created the public museum as we know it. ${ }^{56}$

The individuals who established the Monuments Commission were for the most part cultivated men proud of their artistic heritage. Among the Revolution's new Ten Commandments in the Temples of

54. Idzerda, Iconoclasm during the French Revolution, 60 AM. HIST. REV. 14 (1954).

55. Its most notable success was in gathering funerary monuments to former kings from churches all over France. These were displayed in the abbey church of St. Denis. P. LEON, supra note 36 , at $68-69$.

56. "That the right to see such collections belonged to all citizens was asserted for the first time on August 10,1793 ... . The Louvre was proclaimed a musée révolutionnaire, open to everyone on three days of the ten day week adopted by the Convention." K. MEYER, THE ART Museum: Power, Money, Ethics 20 (1979). The Luxembourg Palace, which housed some paintings, was open to the public two days each week prior to the Revolution. E. KENNEDY, supra note 13, at $431 \mathrm{n.42}$ (citing C. Gould, Trophy of CoNQuest: THE MusÉ NAPOLEON AND THE CREATION OF THE LOUVRE 19-20 (1965)). The British Museum was chartered in 1753 by Parliament and supported by public revenues, but was open only to approved visitors who made written applications in advance. K. MEYER, supra, at 20. There is no undisputed candidate for the first genuinely public museum in the modern sense. The Uffizi in Florence was converted in 1743 from a princely art gallery into what one author has called "the first of Europe's truly major public art museums." J. ALSOP, supra note 47 , at 118 . The same author also says, however, that the Museo Capitolino in Rome "should probably be regarded as the first public art museum," having opened its doors in 1471. Id. at 164. 
Reason, for example, number six read: "Thou shalt cultivate the fine arts; they are the ornament of the state."57 But these individuals were creating a revolution devoted to repudiation of everything associated with the ancien régime, a regime whose social, political, and religious values were represented in pre-revolutionary art. As Diderot said, "The governors of men have always made use of painting and sculpture in order to inspire in their subjects the religious or political sentiments they desire them to hold." 58 Could the values of the old order be eradicated without eradicating its most prominent physical evidences?

From 1789 until about 1792, the revolutionary government leaned in favor of cultural protection. But what began as a general commitment to protect artifacts unravelled under both ideological and popular pressures, and ambivalent legislation became a regular and bizarre feature of the Revolution. In 1790, for example, a decree that generally forbade the mutilation of monuments included a specific provision mandating the destruction of some bas-reliefs at the foot of a statue of Louis XIV because they represented French provinces in chains. ${ }^{59}$ In 1792, after the uprising of the Paris Commune, the move toward official iconoclasm gathered force. A decree of May 12, 1792, referred to the need to "eliminate the marks of feudalism and the memories of despotism." 60 On August 14 of that year, a law was enacted with this preamble:

Whereas the sacred principles of liberty and equality will not permit the existence of monuments raised to ostentation, prejudice and tyranny to continue to offend the eyes of the French people; whereas the bronze in these monuments can be converted into cannon for the defense of the homeland, it is decreed ... [that all] monuments containing traces of feudalism, of whatever nature, that still remain in churches, or other public places, and even those outside private homes shall, without the slightest delay, be destroyed by the communes. ${ }^{61}$

This law was enacted in the wake of mob action during which cheering

57. Freedberg, The Structure of Byzantine and European Iconoclasm, in ICONOCLASM: PAPERS Given AT THE Ninth SPRING Symposium OF Byzantine Studies, 1975, at 165, 175 (1977).

58. Idzerda, supra note 54, at 13 (quoting DIDEROT, Peinture, in 12 ENCYCLOPÉdIE 267 $(1751-65))$.

We know that this hostility toward one's own medieval past was a governing assumption, a chief stock in trade of the Party of Humanity.... We have no difficulty in understanding Saint-Just when he calls Louis XVI "a stranger in our midst" and proclaims that "no king can reign innocently."

Mellon, Alexandre Lenoir: The Museum versus the Revolution, in 9 THE ConsorTium, supra note 10 , at 75,84 .

59. Idzerda, supra note 54 , at $15-16$.

60. Mellon, supra note 58, at 81 .

61. F. RƯCKer, supra note 8, at 22 (quoting Procès-verbal de la législative, tit. XII, at 212). 
crowds tore down statues of French kings all over Paris. The revolutionary government mandated the destruction of statues erected in honor of despotism in order to demonstrate to the people that the Assembly was aware of their regard for liberty. ${ }^{62}$ Even so, a provision of the law instructed the Monuments Commission to conserve those items which have a particular interest for the arts. ${ }^{63}$ A month later, the new government issued a second decree, this time emphasizing conservation, rather than leaving it as a proviso to the prior iconoclastic order. ${ }^{64}$

This curious duality of simultaneously ordering destruction and preservation continued all through 1793. The government's efforts to purge the memorials of the old regime were aided by the additional destruction being carried out in the streets of Paris. People tore precious engravings out of art shops simply because they had stamps of nobility on them. ${ }^{65}$ Ecclesiastical structures were special targets, especially following the assassination of Marat.

[A] church would be inaugurated as a Temple of Reason, a bust of Marat would be unveiled, and a bonfire composed of statues, paintings, charters, and armorial bearings would be lit. ... [A]t Fontainebleau ...

[i]t was proudly recounted how"the smoke from Champagne's portrait of

Louis XIII "was wafted toward the bust. It was the most agreeable incense we could offer [Marat]."66

The inconsistency of a policy simultaneously urging both destruction and preservation was never resolved by the revolutionary legislatures. But the excesses of the Terror in 1794, and the execution of Robespierre in July of that year, set the stage for receptivity to the ideas the Abbé Grégoire was about to make public.

\section{The Abbe Gregoire Enters the Scene}

Prior to the work of the Abbé Grégoire, there was no rationale available to counter Diderot's quip of a generation earlier: "[I]f we love truth more than the fine arts, let us pray God for some icono-

62. 48 ARChIVes PARLeMENTAIRES DE 1787 À 1860 (première série) 2 (1792).

63.. Id. at 115-16.

64. A decree of September 16, 1792, began with the words, "Considering that in delivering to destruction those monuments that properly recall memories of despotism, it is important to preserve and conserve honorably the masterpieces of art that are worthy to occupy the leisure and to embellish the territory of a free people ...." Babelon \& Chastel, supra note 5, at 19.

65. Guillaume, Grégoire et le vandalisme, in LA REvolution FRANÇAISE 155, 159 (A. Aulard ed. 1901).

66. Idzerda, supra note 54, at 17 (quoting 77 ARChIVEs ParLIAMENTAIRES DE 1787 \& 1860 (première série) 650 (1793)). 
clasts." 67 While others had spoken out against revolutionary destructiveness, ${ }^{68}$ Grégoire was the first to propose a rationale for preservation as a public duty based on the Revolution's self-proclaimed political values. The question he posed was not why is art or history important, but rather what does the spirit of liberty require? And to this question he offered three answers. First, that liberty is only realized where the talent and creative energies of the individual flourish. Second, that only where tolerance for difference and respect for creativity exist can that flourishing occur. And third, that the pursuit of knowledge and repudiation of ignorance are essential to a process where talent and creativity will blossom. Grégoire's reports on vandalism applied these precepts to the cultural life of France.

Grégoire's first task was to respond to arguments urging destruction of "tainted" art. As the quotation from Diderot reveals, this argument was not simply a response to mob fury, but exposed the view that artistic things are especially dangerous because they conceal falsehood under a mask of beauty. Grégoire's answer was to urge a focus on the creator of art rather than on the patron, to bring the individual to the forefront and to present works of art as examples of the free spirit - genius and talent realized ${ }^{69}$ - triumphant over political repression, error, and superstition. He made this point not by argumentation, but by illustration. In his third report on vandalism, Grégoire wrote:

Certainly the temple of the Druids at Montmorillon, and that of Diana at Nimes, were not built by the hand of reason; and nevertheless is there any true friend of the arts who would not want them to be preserved in their entirety. Because the pyramids of Egypt had been built by tyranny and for tyranny, ought these monuments of antiquity to be demolished . .. [?] $]^{70}$

By using such striking examples, and drawing on the then-widespread admiration for the ancient world, Grégoire set out to de-politicize art by showing that no patron's motives, however base, can demean the genius of the artist; that the human spirit can never be made the mere instrument of tyranny. ${ }^{71}$ This was in fact a more revolutionary con-

67. Id. at 13 (citing 3 MAGAZIN ENCYCLOPÉDIQUE $52-53$ (1795) (quoting Diderot's critique of the Salon of 1765)).

68. See supra note 10.

69. Grégoire employed certain words that are not easily translated into English, most importantly génie. $\mathrm{I}$ have used the word genius, recognizing its inadequacy. Génie indicates a special bent or talent, in addition to genius. He also frequently speaks of lumières, which invokes the values and sensibilities of the Enlightenment, and that had a very particular historical meaning in the late eighteenth century. I have tried to convey some of what Grégoire meant in posing the competing forces of knowledge on one side and ignorance and superstition on the other.

70. H. GREGOIRE, Troisième rapport sur le vandalisme, in 2 OUUVRE, supra note 7, at 352.

71. Grégoire was not so naive as to doubt that politics used art to its advantage, and that the 
ception of art than that of the iconoclasts, for the Revolution aspired to free the individual from subjection to a master, and that is just what Grégoire did through his conception of art. The ability to see art as the work of the individual genius behind the aristocrat or clerical patron was a radically modern and secular idea. It is what Grégoire meant when he said "one slanders liberty in supposing that its triumph depends on the conservation or the destruction of a figure where the finger of despotism has left its imprint."72

Grégoire saw cultural properties as central to the political life of the country in another sense, however. The Revolution, after all, was remaking the nation without the institutions of the crown and the church that had essentially defined it. How was the new Republic to define its essential quality? Grégoire answered that the essential quality of the Republic reposed in the genius of individual citizens as revealed in the achievements of science, literature, and the arts. The body of artifacts that embodied the best of the people was the quintessence of France, its true heritage and patrimony. Those who were willing to see these artifacts destroyed, or sold abroad as if the nation cared nothing for them, he said, were imperiling the most important symbols of the national identity, those things that spoke for what France should aspire to be. ${ }^{73}$

In response to those who demanded destruction of hated symbols as a test of patriotism, Grégoire offered his own definition of what it meant to be a patriot in a nation committed to liberty. The true patriot embraces the spirit of liberty, encouraging full realization of the individual's own talent and creativity by protecting those things that express the spirit and that can serve as models and inspirations for the

artifacts of culture could take on political significance. Indeed, he made the point himself in discussing reform of the French language, one of his favorite subjects: "Doubtless the moment is approaching when terms like 'cow' and 'manure' will possess in our republican language a value corresponding to that which these things have in reality, while words like 'princess' and 'courtier' will be relegated to a style considered ridiculous and abject." W. AsHBOURNE, supra note 7, at 75 (quoting Grégoire).

Nor, indeed, did he at first entirely escape the temptation to speak of "soiled" verses not worthy of preservation. H. GREGOIRE, Rapport sur les inscriptions des monuments publics, in 2 OEUVRES, supra note 7, at 149. It is rather that he came to see this as a dead end, viewing tolerance, knowledge, and exposure to genius as the crucial issues.

72. H. GREGoIRE, Rapport sur les destructions opérées par le vandalisme, et sur les moyens de le réprimer, in 2 OEUVRES, supra note 7, at 265.

73. Uncharacteristically, and in a passage of dubious reasoning, Grégoire praised the looting of foreign art treasures as showing French appreciation of culture:

More than the Romans, more than Demetrius Poliocetes, we have the right to say that in combatting the tyrants we protect the arts. We gather their monuments even where our victorious armies penetrate.... The Republic acquires by its courage what Louis XIV was never able to obtain with huge sums of money. Crayer, Van Dyck, and Rubens are en route to Paris and the Flemish school is being taken en masse to come grace our museums. Id. at 273-74. 
future. This was Grégoire's politically adroit riposte to the iconoclasts, turning the tables on them by appropriating the call to patriotic behavior to his own cause. ${ }^{74}$

Finally, and most importantly, Grégoire's reports engaged the fundamental struggle between knowledge and ignorance, and tolerance and fanaticism, that was dramatically being played out in revolutionary politics. The Revolution saw itself as freeing the people from an oppressive past and creating a new world. So far so good. But to toss onto the revolutionary bonfires all the works of the past was, to Grégoire, to demean the notion of liberation by converting it into a celebration of willful ignorance. This was the Revolution at its most ominous. Grégoire took it upon himself to redefine liberation in a way that did not disvalue the past. He did this by presenting past achievement as a form of necessary capital that the citizens of the newly liberated nation would have to employ to create their new society. ${ }^{75}$

Though it is familiar now, the image of public capital, of cultural artifacts as common intellectual and aesthetic assets, was novel then. ${ }^{76}$ "The productions of genius and the means of instruction are common

74. Grégoire faced an awkward tactical problem. Since the revolutionary government itself had decreed in favor of iconoclasm, and the French people were out in the streets doing the destructive acts, the question was, were they the enemies of France and of the Revolution whom he had identified? Plainly that could not be the implication of his formulation, so Grégoire invented a villain out of necessity. The enemies of the Revolution were known - they were the foreigners who wanted it to fail, the emigrés who had deserted it, and the counter-revolutionaries within the country. It had to be they who were responsible for the destruction, neglect, and sale abroad of the treasures of French genius. Grégoire's thrust was probably never meant to be taken as anything more than a convenient fiction. He certainly knew what was actually going on.

75. H. GREGOIRE, Second rapport sur le vandalisme, in 2 CEUVRE, supra note 7, at 331 ("[T] he monuments of art . . . are the glory of the nation and . . . are a part of its wealth.").

76. This way of conceiving of cultural property was picked up and made famous by John Ruskin:

They [the buildings of past times] are not ours. They belong partly to those who built them, and partly to all the generations of mankind who are to follow us. . . Did the cathedral of Avranches belong to the mob who destroyed it, any more than it did to us, who walk in sorrow to and fro over its foundation?

J. RUSKIN, SEVEN LAMPS OF ARCHITECTURE 201-02 (1969). Victor Hugo similarly lashed out at real estate speculators who were tearing down admirable monuments of the Middle Ages: "There are two elements in an edifice, its utility and its beauty. Its utility belongs to the owner, its beauty to everyone; it thus exceeds an owner's right to destroy it." Hugo, Sur la destruction des monuments en France, in 2 OEUVRES COMPLÈTES, 571-72 (J. Massin ed. 1967).

Others prior to Grégoire had hinted at a special status for cultural property, but stopped short of developing the idea. Lakanal, for example, had urged protective legislation for works of art, arguing that "they belong to all citizens in general; not to any one of them in particular; thus, it is with the rights of the entire city [of Paris] in hand, that I ask you to protect the arts against the new losses that threaten them." 66 ARCHIVES PARLEMENTAIRES DE 1787 A 1860 (première série) 98 (1793). The legal notion of things belonging to no one, or belonging to everyone, or sacred and unavailable for purchase and sale, appears in Roman law. W. BuCKLAND, A TEXTBOOK OF ROMAN LAw 182-84 (3d ed. 1963). But the idea that certain things were not.just ordinary property to be disposed of at the will of the owner (even the state), was not the general understanding of the legal status of cultural properties. 
property,"77 Grégoire said, "national objects which, belonging to no one, are the property of all."78 Terms like "common property"79 and "common heritage" 80 appear frequently in his discourses. Cultural artifacts were not only the property of the new nation in a legal sense, but were inherently something that "belonged" - and in right had always belonged - to the nation as a whole. In describing how treasures that had previously been locked up in the castles of the aristocracy would now go into public museums Grégoire said "the people recover their property."81

In the same vein, Grégoire said "a great man is a national'property," 82 and his campaign to protect artifacts went hand in hand with his efforts to protect the creative people who were being persecuted. In this setting, Grégoire's cultural policies and his views about tolerance fused. Just as vandals burned books and destroyed sculptures and paintings, they also victimized individuals of talent. Again, Grégoire believed, willful ignorance masqueraded as revolutionary fervor. As Grégoire put it:

On one side one sees the blockheads slander talent to console themselves because they have been deprived of it, and to assert gravely, without distinction of ability either useful or harmful, that a learned person is a scourge on the state....

On the other side ... they propose to burn the libraries: theology they say, because it is fanaticism; jurisprudence because it is chicanery; history is lies; philosophy is dreams; the sciences, one has no need of them. ${ }^{83}$

In his reports, he spun out a vision of an advanced, free, and prosperous society, showing exactly why it should nurture philosophers, scientists, and poets, in terms that even the "blockheads" would understand.

\section{Grégoire's Battle Against IgNorance}

The notion that the new liberated nation should be a place of sim-

77. MEMOIRES, supra note 13, at 58-59.

78. H. GREGoIRE, Rapport sur les destructions opérées par le vandalisme, et sur les moyens de le réprimer, in 2 OEUVRES, supra note 7, at 277.

79. H. GREgoIRE, Rapport sur la bibliographie, in 2 OEUVRES, supra note 7, at 206.

80. Id. at 211 .

81. H. GREGoIRE, Rapport sur les destructions opérées par le vandalisme, et sur les moyens de le réprimer, in 2 OEUVRES, supra note 7, at 273.

82. Id. at 269. Grégoire defined "national property" when speaking of the selfish desire of certain localities to keep their libraries and art to themselves: "What is national does not belong to anyone, it belongs to everyone." H. GREGOIRE, Rapport sur la bibliographie, in 2 CEUVRES, supra note 7, at 203.

83. H. GREgoIRE, Rapport sur la bibliographie, in 2 OEUVRES, supra note 7, at 209. 
ple virtues was not an invention of the Revolution. ${ }^{84}$ But the Revolution generated a strain of know-nothing politics of the most extreme kind. A notable example was the proposal that there should be no requirement of literacy in order to be an officer in the army. ${ }^{85}$ One delegate to the Convention asserted in 1793 that "any inclusion of the fine arts in the education of children would 'corrupt morals' ... [and] [a]ny enjoyment from the fine arts ... 'would make men insensible to the charms of moderate means and simplicity which are so indispensable in a republic." "86

The Revolution's anti-intellectualism manifested itself in destruction. One community proposed to burn all books relating to 1 aw. ${ }^{87}$ Another wanted to get rid of all books that were "licentious, absurd or counter-revolutionary." all his books because they were either 'useless or evil." "89 As Grégoire remarked, "[H]ow can one avoid a just indignation when book burnings are justified by telling us that the volumes were badly bound?" 90 "They have judged books by their cover as fools judge men by their clothing." 91 The fact is, he said, that there exists, "I won't say a mania, but a furor to destroy and to deliver things to the flames."92

Revolutionary politics in this context made cultural policy inescapably a public matter. Grégoire, perhaps alone even among those who worked for preservation, saw it as not only a matter of protecting certain artifacts, but as a much broader issue of public values. The battle, he said, was against those whose motto was: "[D]istrust that man, for

84. "Prominent in the winds of doctrine that blew over eighteenth-century France was the notion that the arts were a result of luxury and vice, that thiy flourished only in decadent, overcivilized societies and provided opiates for the subjects of tyrannical rulers." Idzerda, supra note 54 , at 19.

85. H. GREGOIRE, Rapport sur les destructions opérées par le vandalisme, et sur les moyens de le reṕrimer, in 2 CEUVRES, supra note 7, at 266.

86. Idzerda, supra note 54, at 20 (quoting 2 PROCÈs-VERBAUX DU COMITE D'INSTRuCTION PUBLIQUE DE LA CONVENTION NATIONALE 551 (J. Guillaume ed. n.d.)). In his memoirs, Grégoire wrote "I heard such members of the Committee [of Public Instruction] tell us confidently that public instruction was useless; that it was only necessary to teach children to read in the great book of nature." MÉmoIRes, supra note 13, at 57.

87. Guillaume, supra note 65 , at 178 n.2.

88. H. GREGOIRE, Rapport sur les destructions opérées par le vandalisme, et sur les moyens de le réprimer, in 2 CEUVRES, supra note 7, at 260.

89. Idzerda, supra note 54, at 20 (emphasis in original) (quoting 3 Prock̀s-VERBAUX DU COMITE D'INSTRUCTION PUBLIQUE DE LA CONVENTION NATIONALE $40-41$ (J. Guillaume ed. n.d.)).

90, H. GREGoIRE, Rapport sur les destructions opérées par le vandalisme, et sur les moyens de le réprimer, in 2 CEUVRES, supra note 7, at 260.

91. H. GREGoIRE, Rapport sur la bibliographie, in 2 OEUVRES, supra note 7, at 204.

92. H. GREGOIRE, Rapport sur les destructions opérées par le vandalisme, et sur les moyens de le réprimer, in 2 OEUVRES, supra note 7, at 259. 
he has written a book."93 Grégoire was fighting the iconoclasts for control of the meaning people attached to what they (literally) saw with their own eyes. A Parisian police report of the time noted: "We are receiving complaints on all sides that the eyes of patriots are offended by diverse monuments raised by despotism during the time of slavery, and which certainly should not exist under a regime of liberty and equality." 94 Grégoire himself said:

The evil is known, let us turn to remedies: the first is education. In a certain sculpture, which is a masterpiece, the ignorant see only a carved stone; let us show them that this marble breathes, that canvas is living, that this book is a veritable arsenal to defend their rights. ${ }^{95}$

Of course what Grégoire called education others might call official propaganda. But whatever the characterization, the issue was a matter for the community at large to address. For the battle was over public commitment, symbolic and substantive, to the premises of art and science as nation-building strategies. The issue was not and could not be simply a matter of private judgment. The presence of books and museums, the encouragement of scientific enterprise and art, and the existence of a discerning public are all elements of a collective enterprise. Grégoire saw revolutionary iconoclasm as not simply an outbreak of violence, or a political act of limited duration, but as a symbolic public statement about public values.

His recognition of the symbolism attached to decisions about cultural property is revealed by the extraordinary vocabulary Grégoire employed in discussing the issue. In his lexicon, to permit or to encourage destruction was "vandalism." Today that is the standard term used in this context, but it was not so at that time. ${ }^{96}$ In fact, the Abbe Grégoire is the inventor of the word "vandalism," a word that has the same form and meaning in both English and French. ${ }^{97}$ "I

93. Id. at 267.

94. Vidler, Grégoire, Lenoir et les "monuments parlants," in LA CARMAGNOLE DES MUSES, 132 (1988). An English version now exists, Monuments Parlants: Grégoire, Lenoir and the Signs of History, 33 ART \& TEXT 12 (Winter 1989).

95. H. GREGOIRE, Second rapport sur le vandalisme in 2 OEUVRES, supra note 7, at 330.

96. The term "barbarous" was used by others during the Revolution, and had long been employed to describe the authors of acts of savagery. Even the phrase "Vandals and Visigoths" had been used earlier to describe those who were destroying books. Marot, L'Abbé Grégoire et le vandalisme révolutionnaire, 49 REVUE DE L'ART 36, 37 (1980); see also Guillaume, supra note 65, at 158. Raphael had also referred to vandals in his letter. 1 A DocuMENTARY HisTORY OF ART, supra note 35, at 291. But it was Grégoire who, by coining a new noun, permanently associated the term with preservation of cultural artifacts as a public policy.

97. 2 The Shorter OXford ENGLish Dicmonary ON Historical Principles 2451 (3d ed. 1973). Grégoire first used the word in 1793 in his Report on Inscriptions in Public Monuments: "one cannot inspire in citizens too much horror for the vandalisme which only knows destructions." H. GREGOIRE, Rapport sur les inscriptions des monuments publics, in 2 OEUVRES, supra note 7, at 149 (emphasis in original). 
created the word to destroy the thing," he wrote in his memoirs.98 Grégoire was an inventive genius in the field of invective, which, consciously or not, gave to cultural policy a moral Manicheism that had not previously existed, but which persists to this day. Grégoire labeled those who destroyed monuments "scoundrels," "counter-revolutionaries," "book-burners," "barbarians," "thieves," "villainous hordes," and "conspirators." The damage they caused, he called "degradation," "dissipation," "pillage," "mania," "destructive furor," "mutilation," "frenzy," “destruction," “fanaticism," "barbarism," "assassination," "destructive rage," and "rascality.",99

Employing these terms, Grégoire made cultural policy a litmus test of civilized values, and located it in the ideological geography of the French Revolution. The nation decides what it will be as it stands before its artistic, historical, and scientific monuments, hammer in hand. As he characterized it, the decision to preserve demands the tolerance crucial to a program of education; education in turn is the underpinning for the exercise of liberty and the nurturing of talent and ability; and liberty, finally, is the key to the nation's greatness. To Grégoire, these were inextricable goals that could only be addressed as part of a public program to honor knowledge, achievement, and the genius that generates both. This is how a nation distinguishes itself. "A prejudice destroyed, a truth acquired," he wrote, "are often more important than the conquest of a city."100 One of the most striking elements of Grégoire's rhetorical style is his repeated use of political terms to describe cultural values, for example: Ignorance is slavery. ${ }^{101}$

Thus, Grégoire believed that individuals should be released from the bondage of their own ignorance. Believing as he did that "[a]11 the arts are brothers,"102 Grégoire spoke in essentially the same terms whether he was discussing the loftiest of the arts or the daily work of a mechanic. "It was in front of a canvas of Raphael that Corregio knew he was a painter: and it was on seeing a pendulum that Vaucauson realized the direction of his talent. It was on reading the meditations

98. MEMOIRES, supra note 13 , at 60 .

99. All the terms have been collected by Vidler, supra note 94 , at 136 .

100. H. GREGOIRE, Rapport sur les destructions opérées par le vandalisme et sur les moyens de le réprimer, in 2 OEUVRES, supra note 7, at 269.

101. H. GREGOIRE, Troisième rapport sur le vandalisme, in 2 CEUVRES, supra note 7, at 355. According to Grégoire, "apologists for ignorance" were, in essence, "for immorality and slavery." In the First Report on Vandalism, Grégoire states that "nothing is more counter-revolutionary than ignorance." H. GREGOIRE, Rapport sur les destructions opérées par le vandalisme, et sur les moyens de le réprimer, in 2 CEUVRES, supra note 7, at 278.

102. H. GREGOIRE, Rapport sur l'établissement d'un conservatoire des arts et métiers, in 2 QEUVRES, supra note 7, at 285. 
of Descartes that Malebranche knew his vocation." 103 The point, put in everyday terms, is that "the artisan who has seen only his own workshop cannot imagine the possibility of a better one. The project [a conservatory of the useful arts] that we are presenting is going to surround him with all the means to incite his emulation and to make his talents bloom."104 Grégoire believed knowledge was liberating and ignorance enslaving not only as a philosophical matter, but as a formula for practical public policy.

\section{ON THe Encouragement of Scientists, Scholars and ARTISTS}

Grégoire knew that a deeper question would persist long after the frenzy of active iconoclasm had run its course: Why, as a matter of public policy, should the ordinary citizen support high culture and the tastes of a handful of offbeat artists and intellectuals? These questions were implicit in what he called the axioms of ignorance. 105 "When I hear it said," he wrote, "that all it takes to be a good farmer are strong arms, I pray that they will let me have a clear head to lead them."106

In his report of October 1794, On the Encouragement, Compensation and Pensions To Accord to Scientists, Men of Letters and Artists, 107 Grégoire offered his response to the claim that a republic of plain and practical virtue required only simple and useful things. He put for-

103. H. GREGOIRE, Rapport sur la bibliographie, in 2 CEUVRES, supra note 7, at 212.

104. H. GREGOIRE, Rapport sur l'établissement d'un conservatoire des arts et métiers, in 2 OEUVRES, supra note 7, at 281, 289; see also Corps legislatif, counseil des cinq-cents, rapport fait par le citoyen Grégoire au nom d'une commission spéciale sur le conservatoire des arts et métlers, in L'ABBE GRÉGOIRE, supra note 7, at 162, 171.

Grégoire made similar observations in his extraordinary discourse on the abolition of patois (regional languages and dialects), which he thought had mired the people in ignorance by cutting them off from modern knowledge and often from the possibility of communicating beyond their own village. H. GrEGOIRE, Rapport sur la nécessité et les moyens d'anéantir les patois, et d'universaliser l'usage de la langue française, in 2 OEUVRES, supra note 7, at 227, 230-31. Before writing his report, Grégoire solicited information on the state of patois from many correspondents. He posed 43 questions, in addition to asking for copies of all the interesting works in each dialect. His questionnaire is itself fascinating. He asked about the usage of the patois and of French, technical use of vowels and consonants, and the use or commonality of synonyms. But he also asked what sort of books people in the community read, and whether and what sort of prejudices they had. And finally, he asked, "[W] hat would be the religious and political significance of destroying entirely the patois?" Grégoire's questionnaire and the responses he received, along with Grégoire's report, are reprinted in LETTRES À GREGOIRE SUR LES PATOIS DE FRANCE, 1790-1794, supra note 18, at 9.

105. H. GRÉGoIRE, Nouveaux développemens sur l'amélioration de l'agriculture, par l'établissement de maisons d'économie rurale, in 2 OEUVREs, supra note 7, at 132.

106. See also H. GREGOIRE, Second rapport sur la vandalisme, in 2 OEUVRES, supra note 7, at 328 ("One already observes that in places where a head is necessary we find men who have only arms.").

107. H. GREGOIRE, Rapport sur les encouragemens, récompenses et pensions à accorder aux savans, aux gens de lettres et aux artistes, in 2 CEUVRES, supra note 7, at 303. 
ward a "seamless web" argument for the support of cultural life. He set out to show that there is no line to be drawn between the speculations and creations of intellectuals and artists and even the most downto-earth concerns of the practical citizen.

To some people, he said, the thoughts of the English philosopher David Hume would seem strange. ${ }^{108}$ Hume said that, in a society where astronomy is ignored and morals neglected, one ought not to expect to find workers capable of making cloth to the degree of perfection that is possible in a society where such arts and values are nurtured. Hume's ideas would seem less paradoxical, Grégoire argued, if connections between disciplines were better understood. "The tree of human knowledge contains all the sciences and the arts, from poetry to algebra, as branches that all grow out of the same trunk and are nourished from the same source." 109 Thus, the study of ancient medals is equally useful to the science of chronology and to theatrical art, furnishing certainty of historical dates to the former while it provides information about contemporary dress to the latter. ${ }^{110}$ Similarly, "anatomy is useful to artists and indispensable to surgeons, guiding the brush that draws the contours of an arm and the hand that restores a dislocation."111

The relation between ordinary life and the higher reaches of science and art was one that intrigued Grégoire. Just as he sought to show that revolutionary ideals were at odds with anti-elitist and antiintellectual attitudes, he was concerned to show that traditional disdain for artisanal activities was equally misguided. He did not argue simply that there was a continuity rather than a disjunction between art and artisanship, or between science and technology. In addition, Grégoire urged, the principle of encouraging talent and promoting knowledge required the government to promote the useful as well as the fine arts. This was the essence of his reports on the establishment of a Conservatory of Arts and Crafts. ${ }^{112}$

108. Id. at 308. Grégoire is undoubtedly referring to Hume's essay of Refinement in the Arts. D. HumE, Of Refinement in the Arts, in Essays: MORAL, POLITICAL, AND LITERARY 268 (E.F. Miller ed. 1985).

109. H. GRÉGoIRE, Rapport sur les encouragemens, récompenses et pensions à accorder aux savans, aux gens de lettres et aux artistes, in 2 QEUVRES, supra note 7, at 309.

110. Id.

111. Id. It would be easy to show in the home, and even in the dress of the most austere Irepublican, Grégoire added, the result of a melding of virtually all the arts as well as the application of the most profound theories of science. For example, it is to chemistry that we owe the beauty and the stability of our dyes. And it is chemistry also that teaches the art of transforming common sand into that diaphanous mass that furnishes us with glass. Id. at 308.

112. Grégoire made two such reports, the first on October 10,1794, reprinted in 2 OEUVRES, supra note 7, at 281, and the second on May 15, 1798, reprinted in 5 GeUVRES, supra note 7, at 37. 
Grégoire's programmatic idea was to

bring together in a single place the vast collection of machines [that the state had acquired] for the establishment of a conservatory where the judgment of what is best can be made, and where the genius of the [industrial and artisanal] arts will reach out to all who cultivate those arts to enlighten and to encourage their work. ${ }^{13}$

Grégoire hoped to bring about a flourishing of French industry that would permit a reduction in imports and thereby make the country more self-sufficient. Grégoire's notion of liberty as the opportunity to make a nation of self-reliant, competent individuals shaped every aspect of his hopes for the new France. "The perfecting of the arts is a principle that preserves liberty; to shake off the yoke of foreign industry is to assure [the nation's] own independence."114 The goal was not simply economic benefit, or national pride as such, but the sense of completeness and fulfillment that comes from making the most of opportunity and possibility. Grégoire offered the Swiss as an example of what he had in mind:

In the valleys and on the mountains of the Swiss I have seen men with the attitude of virtuous and proud liberty, behind their plows and at the head of their herds, carrying a shepherd's crook, a sword and books. This is the way the French have to learn to govern themselves, to be selfsufficient and to defend themselves. ${ }^{115}$

At first, Grégoire's unabashedly utilitarian approach surprises, coming from one who himself revelled in the intellectual life. ${ }^{16}$ Perhaps the answer is that he was a meliorist at heart. Or perhaps philosophically he was trying to conceive the idea of a single nation of citizens - farmers and artists, mechanics and scientists - bound together in a common enterprise called liberty, each aspiring to the fullest use of the capacities with which each has been endowed. He knew that his image of liberty was especially likely to be lost in a time of militant egalitarian sentiment: "The life of a man of genius is almost

113. H. GREGoIRE, Rapport sur l'établissement d'un conservatoire des arts et métiers, in 2 OEUVRES, supra note 7, at 286.

114. L'ABBE GREGOIRE, supra note 7, at 167.

115. H. GREGOIRE, Rapport sur l'établissement d'un conservatoire des arts et métiers, in 2 OEUVRES, supra note 7, at 298.

116. It was a standard Enlightenment view that nothing was justifiable that would not be shown to be useful. W. DOYLE, THE OXFORD HISTORY OF THE FRENCH REVOLUTION 49 (1989). Grégoire sometimes reflected that view in its cruder forms. "I share the opinion," he wrote in his memoir, "that the fine arts in our modern times have usurped a position beyond what their real value would assign them ... they are the product of luxury and that ignoble origin shows in the often depraved morals of artists." MÉMOIRES, supra note 13, at 69. Speaking of the free-spending patronage of Louis XIV, he opined that a certain modern plow, if it turned out as successfully as was hoped, would be "more precious than all the masterpieces of the Louvre. I don't claim to proscribe the fine arts, but to put them in their place." Id. at 135. Despite these words, Grégoire was in practice unremittingly supportive of the arts, artists, and artistic freedom. 
always strewn with thorns. He is ahead of his century: he is treated as an outcast."117 Grégoire concluded with this elegant image:

The edifice of human understanding is . . . formed of material put together stone by stone. No one could be so presumptuous as to believe himself capable of taking all the reports of a new truth and deducing from it all the consequences, in assigning value to it for all the centuries to come. A discovery may appear to be nothing but a hollow speculation. What practical value does it have? Time will teach us in determining its application to the arts and the new chemistry ... will reveal to us many other marvels. ${ }^{118}$

The concept of knowledge as freedom, and tolerance as the key to knowledge, tied it all together for the Abbé Grégoire. One could never imagine Grégoire supporting the arts on the ground advanced by his contemporary, the museum pioneer Alexandre Lenoir, who was always struggling to get in line with the appropriate revolutionary rhetoric of the day: "The cultivation of the arts among a people... . cleanses its morals, [and] renders it more obedient and more submissive to the laws which govern it ...."119 On the contrary, Grégoire believed that support of creativity would be liberating. He had an unshakable confidence too that support of art and science would be rewarded in this world. 120 Whether or not practical gains were one's goal, however, he thought it essential to make the same commitment to support and sustain "the edifice of human understanding."

\section{The Problem of Official Taste}

Today every thought of cultural policy is haunted by the specter of a government bureaucracy saying what is art and, even worse, telling us what cannot be art. The Abbé Grégoire himself had little to say. directly about such questions. He lived in an age when canons of taste were far clearer and the "de-definition of art"121 had not yet been

117. H. GREGoIRE, Rapport sur les encouragemens, récompenses et pensions à accorder aux savans, aux gens de lettres et aux artistes, in 2 OEUVREs, supra note 7, at 305.

118. Id. at 309.

119. A. LENOIR, DESCRIPTION HISTORIQUE ET CHRONOLOGIQUE DES MONUMENTS DE SCULPTURE REUNIS AU MUSÉ DES MONUMENTS FRANÇAIS 1 (6th ed. 1802), quoted in Chapu, Le musée national des monuments français, 49 REVUE DE L'ART 40 (1980).

120. In the broadest sense, Grégoire was certainly a utilitarian. In the Report on the Conservatory of Arts and Crafts, Grégoire advocated that "all the sciences [should] lead toward a goal of utility and [that] the point of coincidence of all their discoveries [should] be the physical and moral prosperity of the republic." H. GREGOIRE, Rapport sur l'établissement d'un conservatoire des arts et métiers, in 2 CEUVRES, supra note 7, at 285-86. But his view of what was necessary to achieve "mere" utility is so broad that the usual critique, though not flatly erroneous, seems very ill-fitted to him: "The Jacobins actually seem to have had little interest in art for its own sake. Their puritanical and utilitarian minds were not attuned to the simple enjoyment of beauty ...." Greene, Alexandre Lenoir and the Musée des Monuments Franģais during the French Revolution, 12 French Historical Studies 200, 206 (1981).

121. H. Rosenberg, The De-Definition of ART (1972). 
imagined. But he was not insensible to the problem:

In general a precious monument is recognized as such. At Moulins, no one ignores that there exists a tomb of great value; $\left.{ }^{122}\right]$ at Strasbourg everyone knows the tomb of Maurice de Saxe, near Pigalle; [123] and on the hypothesis that for lack of knowledge and [cultivated] taste one does not know how to evaluate these objects, where does one turn? There is no more sage advice than that maxim of the philosopher: When in doubt, abstain. ${ }^{124}$

Uneasiness about official winnowing of good art from bad would not have been a strong factor in Grégoire's thinking about the problem. For him, the issue was not to find some external standard that defined artistic greatness or historical importance, but to bring the nation to an appreciation of talent, knowledge, and genius by an exposure to the greatest achievements of every time, recognizing that we can only do our best to identify genius, making an effort that yields as little as possible to contemporary political imperatives or to current fashion. ${ }^{125}$ While one cannot always avoid error, at least one can avoid building error into the system, as by thinking of some art as "tainted," or of certain other times as "barbarous" in their tastes.

That done, one can only rely on the honest judgment of taste educated by broad exposure and tolerance. Grégoire seems to have seen the task not so much as a bureaucratic enterprise, but as an ongoing process of national self-education and self-definition. He focused on making artifacts widely available and on stimulating a taste for knowledge and an acceptance of intellectual and artistic "outliers," those on the frontiers of knowledge and creativity. ${ }^{126}$ If these efforts do not

122. According to Guillaume, Grégoire refers to the funerary monument of Henry, the last duke of Montmorency, put up by his widow, the princess of Ursins. Guillame, supra note 65, at 265 n.1. It is found in the former Convent of the Visitation, today the Lycée.

123. The Marechal de Saxe, a French general and one of the great military leaders of his time, was born in 1696. He was the son of August II, the elector of Saxe, and the king of Poland. He was the grandfather of the writer George Sand. His elaborate mausoleum is found at SaintThomas de Strasbourg.

124. H. GRÉcoIRE, Rapport sur les destructions opérées par le vandalisme, et sur les moyens de le réprimer, in 2 OEUVRES, supra note 7, at 276.

125. "Let us open our breast to all the friends of science and of liberty; let us encourage all the talents, all the free societies, which, closing their doors to mediocrity, admit only genius [le génie]." H. GREGOIRE, Troisième rapport sur le vandalisme, in 2 OEUVRES, supra note 7, at 356.

126. Grégoire himself vigorously championed the merit of Gothic architecture when it was out of style:

The monuments of the Middle Ages present a double interest for conservation, both as structures and as objects of art .... [W] have been tardy in concerning ourselves with gothic edifices which, by the marvels of their construction, the lightness of their columns and the strength of their arches, command our admiration and furnish a model for art.

H. GREGOIRE, Troisième rapport sur le vandalisme, in 2 OEUVRES, supra note 7, at 354. Grégoire expressed similar sentiments in the Second rapport sur le vandalisme, in 2 OEUVRES, supra note 7, at 326.

Though Grégoire was by no means the only eighteenth-century admirer of medieval buildings, he was certainly well in advance of most of his contemporaries. Rousseau, for example, 
generate a public taste and appreciation for genius, the enterprise is probably hopeless anyway. He thought of the problem globally, as a question of public education and reliance on a cultivated public taste that would reflect and be reflected in official action. In that sense he was a democratic republican, but with one crucial qualification. He believed democracy and ignorance were a disastrous mixture.

Though Grégoire never provided any detailed program for identifying heritage properties, he left something else: a reflection on sorting through all the various efforts of the human heart and hand. Considering the revolutionary times, and the considerable opinion in favor of burning forthwith all books, or at least all "bad" books, the passage that follows can only be described as extraordinary:

Despite the decrees which prohibit the sale and destruction, some administrators would still like to arrogate to themselves a right of life and death over the books of the nation; their functions are to conserve, to put in order, to speed up the preparation and the delivery of lists. The moment for pruning will come; but it is necessary to know what we have before knowing what we will keep.

Certainly few writers get brilliant reviews from posterity. Although, on the library of Alexandria, one reads these words: Treasure of the cures of the soul, like our libraries, undoubtedly that one contained its share of reveries which are scandalous to reason. These vast reservoirs of thoughts, these projects of all the centuries, of every country, are at once the shame and the glory of the human species.

But it appears that mankind is destined to feel its way along the path of opinions, to traverse all the routes of error, before attaining the truth. False ideas and absurd systems have at least the advantage to provide on the spiritual level the function of a buoy, they mark the hazards. It is not always true to say, as Fontenelle claimed, that children do not learn from the mistakes of their parents. Thus a well done history of feudalism, which was one of the great errors of the human spirit, would be a quite philosophic morsel. The knowledge of departures from reason arms one against new failures. The recitation of the crimes of tyrants commits them in a more striking manner to the anathema and the execration of the centuries.

When we shall have put together the general catalog we will call on taste and philosophy to exploit this fecund mine to search out the grain of gold even in the mire of silly books.... As to those [books] that will be put on the index of reason, they can still become the objects of exchange with foreign nations, and procure for us books of theirs which we are missing and which would not be unworthy to enter in the libraries of a free people. The spirit of discernment will govern the sorting, the spirit

wrote of "the remains of barbarism and false taste, which subsist, like the porches of our Gothic churches, only to reflect disgrace on those who had the patience to construct them." ROUSSEAU, A Letter on French Music, in The Miscellaneous WORKS OF MR. J.J. RousseaU, at 89-90 (1767). Similar condemnations from other eighteenth-century writers like Montesquieu, Voltaire and Fénelon are quoted in P. LEON, supra note 36 , at $41-42$. 
of justice the distribution. ${ }^{127}$

\section{GREGOIRE's LEGACY}

History played a cruel trick on the Abbé Grégoire. The cause of cultural preservation that he championed has ultimately prevailed, but under circumstances that virtually assured that he would be ignored. Though the worst of revolutionary iconoclasm abated as the Terror ended in 1794, Grégoire's hopes for a positive program to protect cultural properties were not fulfilled. Neglect, insensitivity, and cupidity permitted the continuing loss of historic and artistic treasures for decades after Grégoire issued his reports. ${ }^{128}$

When a state program for the protection of historic monuments was finally established in 1830 , it was under the restored monarchy of Louis-Phillipe. The monarchy had no use for Grégoire's republican ideology. Indeed, the arch-conservative François Guizot, who as Interior Minister was responsible for the preservation program, wrote in his memoirs that the newly developed taste for the ancient monuments of France was attributable to the intellectual stimulus of the restored monarchy. ${ }^{129}$

Guizot was probably right. The public constituency for preservation was formed by a wave of sentimental chauvinism that had welled up and come to dominate popular literature. Ancient castles, romantic ruins, mysterious abbeys, and an interest in a remote and heroic national past became the order of the day. National pride was on the march and it revealed itself in a predilection for ancestral glories, some real and some mythical. ${ }^{130}$ As a result, to this day preservation is often perceived as having nothing more behind it than backward-looking sentimentality.

Under the circumstances of the time, Grégoire's idealism and revolutionary rhetoric were bound to be discarded, though his way of conceiving of cultural property has set the terms of reference even to this day: preservation as a state responsibility; cultural property as "belonging" to the nation regardless of formal ownership; and creative

127. H. GREgolRE, Rapport sur la bibliographie, in 2 OEUVRES, supra note 7, at 210-11.

128. The great medieval abbey at Cluny, for example, was destroyed in 1823. J. ALsor, supra note 47 , at 12 . As late as 1831 , an archeologist told the story of coming upon a medieval chapel in Normandy that had been divided in two, the lower part serving as a stable and upper story as a granary and pigeon coop. Cattle horns were marring the fine sculptures and pigeons were ruining the magnificent paintings on the vaulted ceiling. Upon protesting, he was told by the farmer: "I have brought Jesus back to his original state. He was born in a cowshed, and he can live perfectly well in a stable." P. LEON, supra note 36, at 262-64.

129. F. RÜCKER, supra note 8 , at 204.

130. See generally id. at 123-212. 
achievement as a national asset. Even his vocabulary has become ours, with terms like "vandalism" and "common heritage." It seems he is forgotten but not gone. And whenever the axioms of ignorance show themselves - asking "who needs art" or "what has all this to do with public responsibility and with the lives of ordinary people" - the Abbé Grégoire stands ready to reply. 